\title{
An Empirical Research into EFL Learners' Motivation
}

\author{
Luu Trong Tuan \\ University for Natural Resources and Environment, Ho Chi Minh City, Vietnam \\ Email: luutrongtuan@vnn.vn
}

\begin{abstract}
Motivation plays a very important role in enhancing the students' English learning performance. Therefore, the research aim is to investigate learning motivation at University for Natural Resources and Environment to find out whether motivation has any impact on students' English learning in order that English teaching together with learning at the school can improve. 290 students and seven English teachers were invited to take part in the questionnaire survey. The findings demonstrated that students have positive towards English learning and motivational activities. They were both extrinsically and intrinsically motivated in the English subject. However, they had many difficulties in succeeding in the English subject and their English learning was influenced by various elements, among which two main factors influencing their English learning most were their personal ways of studying and the heavy learning curriculum with difficult textbooks. Teachers' attitudes as well as their perceptions toward learning motivation are positive since they all find the necessity of motivation in improving students' English performance.
\end{abstract}

Index Terms - intrinsic motivation, extrinsic motivation, EFL learner, L2

\section{INTRODUCTION}

Numerous researchers investigated the influence of motivation on students' learning. Dornyei (1997) put a stress on the influence of motivation that motivation is considered as a key to learning a second language (L2) and it seems to be the biggest single factor affecting language learners' success. Dornyei (1997) stated,

"L2 motivation provides the primary impetus to initiate the learning behavior and later the driving force to sustain the long and often tedious learning process; that is, all the other factors involved in L2 acquisition presuppose motivation to some extent and, indeed, motivation is usually mentioned in explaining any L2 learning success or failure" (Dornyei, 1997, p. 261).

In addition, in Wood's (1998) perception, one of the factors influencing how successful a person in learning a L2 is the nature of the person's motivation. Lack of motivation is observed to have led to low attendance, participation, and performance of the students at University for Natural Resouces and Environment, Ho Chi Minh City. The study seeks to examine what are key motivational factors influencing students' English learning performance and some effective ways of fostering these factors. This study, thus, is guided by the ensuing questions:

1. What motivational factors influence the students' English learning performance?

2. How can learning motivational factors be enhanced?

\section{LITERATURE REVIEW}

A learner's L2 acquisition was influenced by motivation (Wood, 1998). To emphasize its effects on students' learning, Crookes and Schmidt (1991) indicated that motivation is crucial in schools due to its powerful influence on students' learning since motivation is a key for students' learning achievements. Thus, students with strong learning motivation often study better than those with less or no learning motivation. Gardner and Lambert (1972) mentioned that motivation can be said to be an essential element in deciding students' learning achievement in which motivation overrides the aptitude which accounts for a considerable proportion of individual variability in language variability in language learning achievement.

Harmer (1991) also agreed that students who are in some way motivated do significantly better than their peers despite their teachers' unsatisfactory methods or unfavourable conditions while students without sufficient motivation can not accomplish long-termed goals in spite of having the most remarkable learning abilities. For these demotivated students, no curricula and teaching methods are appropriate or good enough to ensure their learning achievements. Therefore, demotivation can result in students' low achievements or negative attitudes toward the target language. Moreover, Dornyei (1997) put it that in language teaching, both teachers and reseachers considered motivation as one of the key factors influencing the rate and success of L2 learning. As language teachers, we can therefore recognize the essential role of motivation in our students' learning and we must consider the concept motivation in order to enhance our students' language outcomes. 


\section{A. What is Motivation?}

Motivation has been differently defined from various perpectives of psychology, sociology and linguistics. Some psychologists defined motivation in terms of certain needs. Ausubel (1968) identified some main needs which help construct learner motivation (1) the need for stimulation, the need to be stimulated by the environment, by other people or by ideas, thoughts and feelings; (2) the need for knowledge, which is defined as the need for achievement (Good and Brophy, 1990), the need to process and internalize the results of exploration, manipulation, activity, and stimulation, to resolve contradiction, to search for solutions to problems and for self-consistent systems of knowlege; (3) finally, the need for ego enhancement, for the self to be known and to be accepted and approved by others.

In L2 acquisition, the types of motivation came from cognitive and social psychology. In cognitive psychology, two types of motivation are instrumental and integrative motivation (Gardner and Lambert, 1972). In social psychology, two main types of motivation are intrinsic and extrinsic motivation (Harmer, 1991).

The concept of motivation came from social psychology (Harmer, 1991) and connected closely to students' effort, desire as well as their positive attitudes towards learning. As stated by Gardner (1985, p. 10), "motivation L2 acquisition refers to the combination of effort plus desire to achieve the goal of learning the language and favorable attitudes towards learning the language".

\section{B. Learner Motivation}

Motivation is closely connected to students'studying, therefore, the problems relating to learner motivation have often intrigued educators and motivation researchers for years. As defined by Lumsden (1994), learner motivation can be considered as students' desire to participate in the language process. Hence, learner motivation can be inferred from a student's behaviour or considered learning motivation which can not be seen, heard or felt and accordingly it is difficult to be deeply understood due to the nature of the concept itself.

In L2 acquisition, not only do students know about the importance of motivation in language learning, but teachers and parents are concerned about its effects on their students' learning as well. Additionally, keeping students interested in school and motivating them to succeed are always challenges for parents, students themselves, and even for almost all the teachers year after year because too many students are not sufficiently motivated to succeed in school (Lumsden, 1994). Discussing the effect of motivation on the L2 acquisition, Finegan (1994) indicated that among the things that clearly affect the mastery of a L2 is the type of motivation that a learner has. Types of motivation will be revisited in the next section.

\section{Types of Motivation}

Theorists and researchers have stressed that it is important to recognize the construction of motivation. Although students may be equally motivated, the source of their motivation may be different and of course, their success in learning will also be different. Arnold (1999) put it that with different expressions and employments of this matter, the researchers have had different points of view in recognizing types of motivation. For many social researchers, two major recognizable concepts of motivation are intrinsic motivation and extrinsic motivation. Noels et al. (2001) claimed that a learner might quit learning the target language soon when the learner is not extrinsically or intrinsically motivated to learn a language.

\section{Extrinsic motivation}

\section{What is extrinsic motivation?}

Extrinsic motivation happens when external factors make the person do something and comes from an external source encouraging or fostering an individual to succeed. As viewed by Harmer (1991), extrinsic motivation is the result of any number of outside factors. In this type of motivation, learners may make efforts to learn a L2 for some functional reasons - to pass an examination, to get a better job, or to get a place at university. For example, people learn English to get better jobs with high salaries in foreign companies. Some students or teachers learn English to get scholarships for their higher study abroad. Therefore, in L2 achievement, extrinsic motivation plays a vital part since the individual desires to learn a L2 because of some pressure or reward from the social environment. Vallerand (1997) put it that extrinsic motivation involves performing a behaviour as a means to an end, that is, to receive some rewards such as good grades or avoid punishment.

\section{Factors influencing extrinsic motivation}

Extrinsic motivation comes from such factors outside the classroom as parents, teachers, friends, or their previous learning, but most often involves subjects in a reward and punishment system. In Brophy's (1987) opinion, motivation to learn is a competence acquired through general experience but stimulated most directly through modeling, communication of expectations, and direct instruction or socialization by others, especially parents and teachers.

In Harmer's (1991) view, parents' expectations are significant to students' school performance, their motivation and their academic achievements since they are generally associated with higher levels of educational attainment. Furthermore, Paige (2001) emphasized that parents are the most powerful advocators in their students' language learning. Harmer (1991) also added that parents have a great impact on students' attitude to the learning language. Whether students have positive or negative attitude toward the language depends mostly on their parents. If the 
parents are very much against the culture of the language learning, this will probably lead to their children's negative motivation whereas many students are willing to study the language in order to meet their parents' expectations.

Like parent factor, students' peers also affect students' attitudes toward the language learning outcomes since students may like learning the language when their peers like it. Furthermore, students' previous learning experiences influence their present learning outcomes. If they were successful, they may be predisposed to learning success now. On the other hand, if unsucessful, they will expect failure now. In addition, the knowledge from their past learning experiences is considered as the knowledgeable background from which they are able to continue to study at present and in the future. Students with good past learning knowledge can study well at present. Information about extrinsic motivation has provided. Another main kind, intrinsic motivation, is mentioned below.

\section{Intrinsic motivation}

What is intrinsic motivation?

In Harmer's (2002) perception, for most researchers and methodologists, intrinsic motivation derived from within the individual is especially important for encouraging students' success in L2 learning. In this type of motivation, the activity itself, not the reward, interests students to learn the language or making themselves better attracts them in the language learning. In addition, as viewed by Vallerand (1997), students are intrinsically motivated in a particular activity when wishing to experience the pleasure and satisfaction of their curiosity from the activity.

\section{Factors influencing intrinsic motivation}

According to Harmer (1991), factors influencing students' intrinsic motivation are physical conditions, teachers as well as their teaching methods.

Physical conditions such as the lighting, the temperature, the acoustic, the lines of vision, the layout of desks, the facilities for displaying pictures or charts, materials and so on, have a great effect on learning. Haynes (1998) mentioned that positive school climate perceptions are protective factors that may supply students with supportive learning environment. For instance, if the students find their classroom is a caring, comfortable and supportive place where everyone is valued and respected, they will tend to participate more fully in the process of learning. Lumsden (1994) added that classroom climate is an important factor influencing intrinsic motivation. Besides, as for Harmer (1991), classrooms that are badly lit and overcrowded can be excessively demotivating because in uncomfortable situations, students may not study as well as in more comfortable ones.

In addition to physical conditions, other factors influencing students' intrinsic motivation are teachers as well as their teaching methods. In Lumsden's (1994) study, school students' level of interest and desire to engage in learning are heavily influenced by such factors as teachers, administrators, the school environment and their classmates. However, among these factors, teachers seem to be the biggest one because their roles are very important in students' learning. Pearse (2000) also pointed out that teachers' feedback mostly affects students' learning motivation especially when they are aware of their students' own progress. For teachers, the key to foster motivation and engagement in learning can lead to good teaching method as well as good teachers, both of which attract students a lot in their learning. If students find their teachers' methodology boring, they will probably become demotivated whereas if they are interested in the method, they will find it motivating so that they can study better.

In Crookes and Schmidt's (1991) view, teachers should motivate students into the lesson, that is, at the opening stages of lessons, remarks teachers make about forthcoming activities can lead to higher levels of interest on the part of the students. Besides, teachers should vary the activities, tasks, and materials because students are reassured by the existence of classroom routines that they can depend on. However, lessons, which always consist of the same routines, patterns, and formats, have been shown to lead to a decrease in attention and an increase in boredom. Thus, varying the activities, tasks, and materials can help to avoid demotivation and increase students' interest levels.

Furthermore, teachers had better use cooperative rather than competitive goals in classrooms. Cooperative learning activities are those in which students must work together to complete a task or solve a problem. These techniques have been found to increase the self-confidence of students, including weaker ones because every participant in a cooperative task has an important role to play. Knowing that their teammates are counting on them can also increase students' motivation.

\section{METHODOLOGY}

\section{A. Participants}

The research data were collated from students and English teachers. The way to select the participants is important for the research success as stated by Hatch and Farhady (1982, p. 8), "subject selection may influence the results of research studies".

\section{Students}

Seliger and Shohamy (1995) put it that there can be no absolute rule regarding the size of the subject population. However, the greater the size is, the smaller the effect of individual variability or any other population-related variable on the research finding. Thus, in the current study, 312 students were chosen from the population of 1569 students in 
stratified randomly selection, which can improve the likelihood of representativeness (Fraenken and Wallen, 2006). For the selection of the research sample, three lists of first-year, second-year, and third-year students in the universityat were first established. After that, from each list, the subjects were randomly selected by closing the eyes and putting the pen into each list at a certain number. Finally, 295 students were selected from the three lists in the interval of five.

Teachers

Seven English teachers were invited to take part in the questionnaire survey. Teachers make great contributions to the research findings since in students' learning process, one of the teachers' important roles is to take the responsibility for motivating students in classrooms.

\section{B. Instruments}

Quantitative method which describes phenomena in numbers and measures instead of words (Wiersma, 1995) was utilized to collect the research data. The quantitative method was used for analyzing some questions in the questionnaires for students and teachers. Questionnaires were defined by Brown (2001) as

"any written instruments that present respondents with a series of questions or statements to which they are to react either by writing out their answers or by selecting from among existing answers" (Brown, 2001, p. 6)

Questionnaires are necessary for investigating learning motivation as Seliger and Shohamy (1989) contend that questionnaires are mainly used to collect data on phenomena which are not easily observed, such as attitudes, motivation, and concepts.

Below were details of two kinds of questionnaires, one for students and the other for teachers.

\section{Questionnaire for students}

Only the students themselves can identify what they need motivating. Poplin and Weeres (1993) put it that listening to the voices of students is increasingly being advocated by researchers concerned with enhancing student motivation. Accordingly, the questionnaire for students is conducted in the research so that their learning motivation can be clearly understood and enhanced. 312 questionnaires were delivered to students; however, merely 290 were returned in the complete responses for the response rate of $92.95 \%$.

\section{Questionnaire for teachers}

Students' learning outcomes are mainly influenced by teachers whose perceptions toward learning motivation play an essential role in bringing effectiveness to teaching and learning at school. Thus, the questionnaire for teachers was made to find out their perceptions toward learning motivation and ways of enhancing learning motivation.

\section{FINDINGS AND Discussions}

\section{A. Findings from Student Questionnaire}

Factors influencing English learning

Five questions were asked to investigate which factors influenced students' English learning most.

TABLE 1.

FACTORS INFLUENCING STUDENTS' ENGLISH LEARNING

\begin{tabular}{llc}
\hline What factor has the most influence on your English learning? & Number of students & $\%$ \\
\hline Ways of learning & 121 & 41.7 \\
Teacher factor & 40 & 13.8 \\
Environment factor & 60 & 20.7 \\
Curriculum factor & 69 & 23.7 \\
Total & 290 & 100 \\
\hline
\end{tabular}

Among the five reasons from the first question as displayed in Table 1, the respondents chose ways of learning (121 students, 41.7\%) as the most influential factor in their learning English as Littlewood (1998) alleges that one of the factors influencing how successful a person in learning a L2 is the student's ability to learn which includes cognitive factors, personality, age and active learning strategies. This high endorsement of the learning strategies (accounting for $41.7 \%$ ) reflected that students knew the importance of learning strategies in their English learning. Thus, with this finding, to enhance students' English learning, teachers should help students find out effective ways of learning English. However, surprisingly, for students, teacher factor was not as important as learning way factor since only 40 students $(13.8 \%)$ thought that teachers influenced their learning English most.

Furthermore, curriculum factor (69 students, 23.7\%) and environment factor (60 students, 20.7\%) were the second and the third influential factors influencing students' English learning. These results indicated that curriculum was so heavy that students' learning was much influenced by too much knowledge from the studyloads. Accordingly, teachers should make every opportunity to make students aware of the interrelations between their English studying and the other subjects in the curriculum (Underwood, 1987) to reduce the pressure of the heavy curriculum.

School environment was also important for students' English learning and thus it needed to become a cooperative atmosphere in which they could study more comfortably and effectively. In Littlewood's (1998) view, the quality of the learning opportunities, which the environment offers has an important influence on the proficiency of students when learning a L2. It can be said from the results in Table 1 that students' English learning were more influenced by individual's personal factors than external factors. Therefore, teachers should instruct students learning strategies so that 
students can know how to study English better. Rubin (1975) stated that good language learners often use better and more leaning strategies than others.

The next question investigates which human factors influencing students' English learning including the three factors: parents, teachers, and peers. Students' responses to this question were described in the Table 2.

TABLE 2.

HUMAN FACTORS INFLUENCING STUDENTS' ENGLISH LEARNING

\begin{tabular}{lll}
\hline Who has the most influence on your English learning ? & Number of students & $\%$ \\
\hline Parents & 45 & 15.5 \\
Teachers & 164 & 56.6 \\
Peers & 81 & 27.9 \\
Total & 290 & 100 \\
\hline
\end{tabular}

This question only focuses on human factors influencing students' English learning. The findings in Table 2 showed that teachers (165 students, 56.6\%) played the most crucial role in students' English learning process. Harmer (2002) put it that teachers play important roles in language learning classroom such as a controller, a prompter, participant or a tutor. Moreover, as for Sparks (2000), one of the most important factors in improving student learning is having a wellqualified teacher in every classroom.

The second influential factor was peers with the proportion of $27.9 \%$ (81 students). Stroud and Wee (2006) indicated that peers could influence students' choices of activities and they can affect how learners conduct themselves in the English language classroom. Furthermore, their peers may make them feel motivated when going to school or doing the homework together.

In addition to teachers and peers, parents ranked third with the proportion of $15.5 \%$ (45 students). From this result, it can be said that students still depend on their parents in their studying.

Surprisingly, there was a contrast in the students' choices of the same option "teachers". In Table 1, teachers did not influence their students' learning as much as learning ways, curriculum and environment factors. However, for the students, teachers were more important than such human factors as parents and peers. Thus, it can be implied that teachers are still an important factor influencing students' English learning at University for Natural Resources and Environment, Ho Chi Minh City.

The aim of the next question is to determine what other factors influence students' English learning most.

TABLE 3.

OTHER FACTORS INFLUENCING STUDENTS' ENGLISH LEARNING

\begin{tabular}{lll}
\hline What is the most influence on your English learning & Number of students & $\%$ \\
\hline School facilities & 18 & 6.2 \\
Textbooks & 11 & 3.8 \\
Teaching methods & 131 & 45.2 \\
Previous learning experiences & 130 & 44.8 \\
Total & 290 & 100 \\
\hline
\end{tabular}

Similar to the findings from Table 2, the data from Table 3 demonstrated the great influence of teachers on the students' English learning through the highest proportion of students (25.2\%) pointed to teachers' teaching methods. Dornyei (2001) put it that one of the factors for demotivating students was teachers' ineffective teaching methods.

The proportion of the previous learning experiences ranked second (130 students, 44.8\%). Yule (1989) indicated that in general students' previous language learning experience would influence their views of learning process.

Merely 18 students $(6.2 \%)$ agreed that one of the influential factors in their English is school facility. For the students, the least important factor was textbooks (11 students, 3.8\%) as it is likely that the textbooks students are learning were published three years ago. Thus, their contents can still interest the students in their studying.

Littlewood (1998) put it that teachers' skills and enthusiasm will be the most important factor in keeping students motivated. Hence, due to teachers' important role in motivating students in the learning process, the researcher asked students to express their views on what is the characteristic a good teacher should have. Following were the results together with the analysis of the responses to this question.

TABLE 4.

CHARACTERISTICS OF A GOOD TEACHER

\begin{tabular}{lll}
\hline The characteristic a good teacher should have is & Number of students & $\%$ \\
\hline Good teaching method & 191 & 65.9 \\
Good personalities & 24 & 8.3 \\
Good relationship with students & 47 & 16.2 \\
Competence to manage the class & 28 & 9.7 \\
Total & 290 & 100 \\
\hline
\end{tabular}

The data from Table 4 showed that the teachers' most crucial characteristic was good teaching methods (191 students, 65.9\%). Moreover, to become more successful in teaching, teachers should vary their teaching methods in different lessons since there is no methodology, which is intrinsically better than others in all situations (Littlewood, 1998). 
In addition, having a good relationship with students ranked second with $16.2 \%$ (47 students) and 28 students $(9.7 \%)$ thought that a good teacher needs to have competence to manage the class. Besides, having good personalities is one of the characteristics of a good teacher (24 students, $8.3 \%$ ). Students should not ignore the role of teachers' personality in their study as Littlewood (1998) indicated that in the classroom, a sympathetic teachers and cooperative environment might have a similarly supportive effect on students' learning.

Almost all classroom activities are based on the contents of the tasks in textbooks. Thus, the next question looks at students' opinions on the tasks in English textbooks.

TABLE 5 .

STUDENTS' OPINIONS ON THE TASKS IN THE TEXTBOOKS

\begin{tabular}{lll}
\hline What do you think about the tasks in the textbooks? & Number of students & \% \\
\hline Very difficult & 14 & 4.8 \\
Difficult & 175 & 60.3 \\
easy & 99 & 34.1 \\
Very easy & 2 & 0.7 \\
Total & 290 & 100 \\
\hline
\end{tabular}

As the data in Table 5 demonstrates, 189 students (65\%) found the tasks in the textbooks difficult and even very difficult. Hence, to motivate students to learn these tasks more effectively, teachers have to supplement as well as change the textbook tasks so that they are more relevant to the students' English proficiency levels. In Littlejohn's (2008) study, learner motivation is considered as the responsibility of the teachers. Therefore, teachers have to design classroom activities for stimulating students to learn by explaining how useful to do a particular activity and how that activity relates to their goal of learning the language for them to see purpose or value in what they are asked to do in classrooms. As a result, the students will be highly motivated in completing the activities.

However, for high-performing learners, they thought that the tasks are easy (99 students, 34\%) and even very easy ( 2 students, $0.7 \%$ ). To motivate these good students in English lessons, teachers should prepare some more challenging exercises beside the tasks in textbooks.

Students' views on motivational activities

Five questions aimed at getting students' views on motivational activities in English lessons.

TABLE 6.

STUDENTS' VIEWS ON MOTIVATIONAL ACTIVITIES

\begin{tabular}{|c|c|c|c|}
\hline Questions & & Number of students & $\%$ \\
\hline \multirow{4}{*}{6.1} & Not necessary & 10 & 3.4 \\
\hline & Not very necessary & 8 & 2.8 \\
\hline & Necessary & 117 & 40.3 \\
\hline & Very necessary & 155 & 53.4 \\
\hline \multirow{4}{*}{6.2} & Role play & 17 & 5.9 \\
\hline & Reading and translation & 92 & 31.7 \\
\hline & Playing games & 104 & 35.9 \\
\hline & Group/ pair work & 77 & 26.6 \\
\hline \multirow{4}{*}{6.3} & Using cassettes for listening & 87 & 30 \\
\hline & Just using textbooks & 33 & 11.4 \\
\hline & Lessons in PowerPoint & 80 & 27.6 \\
\hline & Using televisions for watching films & 89 & 31 \\
\hline \multirow{4}{*}{6.4} & Giving bonus marks & 88 & 30.3 \\
\hline & Showing ways of English self-study & 136 & 46.9 \\
\hline & Offering praise & 39 & 13.4 \\
\hline & Designing challenging exercises & 27 & 9.3 \\
\hline \multirow{4}{*}{6.5} & Applying new teaching method & 57 & 19.7 \\
\hline & Paying more attention to low-performing students & 76 & 26.2 \\
\hline & Design exercises more suitable for students' level & 66 & 22.8 \\
\hline & Helping students' with their difficulties with English & 101 & 34.8 \\
\hline
\end{tabular}

As the findings from the responses to Question 6.1 in Table 6 displays, it is a good sign that most of the respondents (272 students, 94\%) agreed that motivational activities are necessary for motivating students in English classes. They all wanted to attend interesting and active classes in which their teachers applied motivational activities to make them study better.

Question 6.2 asks students which activities they find motivating in English lessons. The data from Table 6 showed that the highest proportion of the participants (104 students, 35.9\%) liked playing games in English classes. As viewed by Harmer (2007), students only enjoy activities, which involved game-like communication and interactive tasks. However, different students have different learning styles and preferences. Therefore, 92 students (31.7\%) liked reading and translation; 77 students (26.6\%) chose group or pair work; and 17 students $(5.9 \%)$ thought that role-play was motivating in English classes.

Question 6.3 is designed to ask which activities the students would like to undergo in English lessons best. Among the four activities, 89 students (31\%) liked teachers to use televisions for watching films in English and to utilize cassettes for teaching listening ( 87 students, $30 \%$ ). They also felt more interested in PowerPoint lessons (80 
students, 27.6\%). Only 33 students (11.4\%) wanted their teachers to teach English by just using textbooks. As viewed by Underwood (1987), students like to have interesting contents in their language lessons, thus, teachers should not be limited to the somewhat artificial world created by language course books.

As regards Question 6.4, students were asked which motivational ways they liked their teachers to apply to encourage them in English studying. This question received a variety of answers from the respondents. Firstly, at the highest proportion, 136 students (46.9\%) did not know how to study English by themselves. Therefore, they wanted their teachers to instruct them ways of English self-study such as using dictionaries or watching films and so on. Knowles (1976) emphasized the necessity of self-study in studying that one of the missions of the teacher is to help individuals to acquire the skills of self-direct learning. Secondly, 88 students (30.3\%) liked getting bonus marks from their teachers in English lessons. Thirdly, they felt motivated when receiving praise (39 students, $13.4 \%)$ from their teachers when they gave correct answers. Finally, 27 students $(9.3 \%)$ would like their teachers to motivate them by giving more challenging exercises.

As for Question 6.5, students suggested what the teachers should do to enhance their present low performance. 101 students $(34.8 \%)$ suggested that teachers should help students with their difficulties with English, especially paying more attention to low-performing students (76 students, 26.2\%). Furthermore, since most of the students found the tasks in textbooks difficult, teachers should design exercises which are more relevant for their low English proficiency level (66 students, 22.8\%). Besides, 57 students (19.7\%) chose the application of teachers' new instructional methods.

The data from Table 6 pointed out that the students' views towards motivational activities are positive. It is good news because students still are very concerned about motivational activities in English subject. The students still can be motivated in English learning when their teachers know how to apply more effectively motivational activities in English lessons. However, to keep students engaged with the learning process, teachers need to try to match the various activities in different lessons so that students do not feel bored (Harmer, 2007) since researchers have shown that learners are different and learn in different ways (Willing, 1988).

\section{B. Findings from Teacher Questionnaire}

\section{Teachers' attitudes toward learning motivation}

Six questions were aimed at determining teachers' attitudes toward learning motivation.

TABLE 7.

TEACHERS' ATTITUDES TOWARD LEARNING MOTIVATION

\begin{tabular}{|c|c|c|c|}
\hline Questions & Number of teachers & Total score & Mean \\
\hline $\begin{array}{l}\text { 1. Learning motivation enhances students' interest in learning } \\
\text { English. }\end{array}$ & 7 & 31 & 4.4 \\
\hline $\begin{array}{l}\text { 2. Learning motivational activities are necessary for students' } \\
\text { English learning. }\end{array}$ & 7 & 33 & 4.7 \\
\hline $\begin{array}{l}\text { 3. Learning motivation has a big influence on students' English } \\
\text { outcomes. }\end{array}$ & 7 & 31 & 4.4 \\
\hline $\begin{array}{l}\text { 4. Enhancing learning motivation can lead to the improvement of } \\
\text { students' English learning. }\end{array}$ & 7 & 31 & 4.4 \\
\hline 6. Students need to be motivated to study English better. & 7 & 33 & 4.7 \\
\hline
\end{tabular}

As Table 7 displays, the means of the six questions ranging from 4.4 to 4.7 revealed that the teachers have highly positive attitudes toward English learning motivation. The high means (4.7) of responses to Question 2 and Question 6 showed that teachers strongly agreed that students needed to be motivated by their teachers because motivational activities are necessary for students' English learning. In Littlewood's (1998) perspective, in L2 learning as in every other fields of human being, motivation is the crucial force which determines whether a learner embarks on a task at all, how much energy he devotes to it and how long preserves.

With the same means of 4.4 in the responses to the other four questions, it can be implied that teachers all agreed that learning motivation has a great influence on students' English outcomes since enhancing learning motivation can improve students' English learning and their interest in learning English.

Teachers' perceptions towards learning motivation

Five questions focuses on getting information about teachers' perceptions toward learning motivation as individual teachers have their own notions of language, which have a great impact on their ways of teaching (Genesee and Upsur, 1999). 
TABLE 8.

TEACHERS' PERCEPTIONS TOWARD LEARNING MOTIVATION

\begin{tabular}{|c|c|c|c|}
\hline Questions & & Number of teachers & $\%$ \\
\hline \multirow{2}{*}{7.1} & Students are not motivated properly & & \\
\hline & Students do not have appropriate learning strategies & 1 & 14 \\
\hline \multirow{3}{*}{7.2} & Learner factor & 4 & 57 \\
\hline & Teacher factor & 1 & 14 \\
\hline & Environment factor & & \\
\hline \multirow{3}{*}{7.3} & Praise & 1 & 14 \\
\hline & Challenging exercises & 1 & 14 \\
\hline & Showing ways of English self- study & 1 & 14 \\
\hline \multirow{2}{*}{7.4} & New teaching method & 2 & 29 \\
\hline & Applying modern technology & 1 & 14 \\
\hline \multirow{4}{*}{7.5} & Attending workshops & 3 & \\
\hline & Reading books, magazines, professional materials & 1 & \\
\hline & Other sources & & \\
\hline & No & 2 & 29 \\
\hline
\end{tabular}

As regards Question 7.1, teachers were asked to choose which factors caused students' low English performance. From the data in Table 8, for the teachers, the most crucial reason behind students' low English performance was their lack of setting study goals (6 teachers, 86\%). Tudor (1996) added that learners may have different types of goals such as needing to academic materials, gaining access to popular songs and films and so on. Nevertheless, these goals can be good or bad for students. From this research finding, in order to make students study better, teachers' duty is not merely to discover their students' functional goals but also to evaluate their perception and awareness of these goals (Tudor, 1996). In addition, only one teacher (14\%) attributed the students' low performance to their lack of having appropriate learning strategies in English studying. It is consistent with Nunan's (1992) view that students with learning strategies become more effective language learners.

Question 7.2 asked teachers about which factors influenced students' English performance. The results in Table 8 showed that three influential factors were learner factor $(57 \%)$, curriculum factor $(29 \%)$ and teacher factor $(14 \%)$. From the findings from the student questionnaire survey as well as teacher questionnaire survey, students and teachers both thought that student factor led to their low English performance. They both claimed that since students neither set learning goals nor had effective learning strategies in their English learning process, they could not have high English learning performance. This idea is true because only students can decide on their own learning success as viewed by Yule (1989), learners become experts on their own language learning needs and through this involvement, to improve their motivation for language learning.

Question 7.3 asked teachers about how the teachers used motivational ways in English classes. Surprisingly, all the respondents stated that they have used various motivational ways in classrooms to encourage students to learn English better. Among the four motivational ways, bonus marks were used most (57\%), followed by the other three ways encompassing praise, giving challenging exercises and showing students ways of English self-study such as how to use dictionaries and so on (14\% for each way).

Question 7.4 required teachers to give their suggestions on which motivational ways they should apply to motivate students better in the future. $57 \%$ of the respondents thought that teachers should organize extra-curricular activities such as English speaking clubs or English competitions. However, two teachers (29\%) found that applying new teaching methods in English lessons would motivate students in their English learning. Besides, $14 \%$ of the respondents suggested using modern technology in English classrooms to make students more motivated in English learning. Ahmad (1985) implied that the computer can be a powerful motivation force for productive study. Thus, teachers should apply more computer technology on English lessons such as preparing PowerPoint lessons to enhance learning motivation at University for Natural Resources and Environment, Ho Chi Minh City.

As regards Question 7.5, teachers responded to what level of their motivational knowledge and how they got this kind of knowledge. Encouragingly, up to $71 \%$ of the teachers had opportunities to be trained or to conduct research on "learning motivation" by studying at university (14\%), attending workshops $(29 \%)$ and reading reference books (14\%). However, two teachers $(29 \%)$ had no chances to learn about learning motivation. From this research finding, the school administrators had better create more opportunities for all the English teachers to get more information about this important issue by buying books on learning motivation for the teachers' reference.

\section{Concluding Thoughts}


Attitudes of the students at University for Natural Resources and Environment toward English learning are positive since they know the role of English in life. Nonetheless, they are not motivated enough due to lack of setting study goals and appropriate learning strategies, which mainly influenced their English learning. Furthermore, for the students, their teachers play the most influential role in encouraging them in their learning process; therefore, they wanted their teachers to motivate them by applying various motivational activities, especially organizing extra activities in English classes. Teachers' attitudes as well as their perceptions toward learning motivation are positive since they all find the necessity of motivation in improving students' English performance. Therefore, they have applied many various motivational ways by organizing different activities in English lessons.

\section{REFERENCES}

[1] Ahmad, K. (1985). Computer language learning and language. Cambridge: Cambridge University Press.

[2] Arnold, J. (1999). Affect in Language learning. Cambridge: Cambridge University Press.

[3] Ausubel, D. (1968). Educational psychology - A cognitive view. New York: Holt Reinhart.

[4] Brophy, J. (1987). Synthesis of research on strategies for motivating students to learn. Educational leadership. Retrieved on May 92011 from http: // www.ppf.ktu.lt/senas/9kakiene.doc.

[5] Brown, J.D. (2001). Using surveys in language programs. Cambridge: Cambridge University Press.

[6] Crookes, G. \& Schmidt, R. (1991). Motivation: Reopening the Research Agenda. Language Learning, Vol. 31, 469-512.

[7] Dornyei, Z. (1997). Motivational factors in the second language attainment: A review of research in Hungary. Acta Linguistica Hungraia. Vol. 44, 261-275.

[8] Dornyei, Z. (2001). Teaching and researching motivation. Harlow: Longman.

[9] Finegan, E. (1994). Language: Its structure and use. Florida: Harcourt Brace.

[10] Fraenkel, J. \& Wallen, N.E. (2006). How to design and evaluate research in education (Seventh edition). New York: McGraw-Hill.

[11] Gardner, R.C. (1985). Psychology and second language learning: The roles of attitudes and motivation. London: Edward Arnold.

[12] Gardner, R.C. and Lambert, E. (1972). Attitudes and motivation in second language learning. Rowley, Mass: Newbury House.

[13] Genesee, F.G. \& Upshur, J.A. (1999). Classroom-based evaluation in second language education. Cambridge: Cambridge Language Education.

[14] Good, T.L \& Brophy, J.E. (1990). Educational psychology: A realistic approach. White Plains, New York: Long man.

[15] Harmer, J. (1991). The practice of English language teaching - Motivational differences. London: Longman.

[16] Harmer, J. (2002). The practice of English language teaching: Describing learners. Harlow: Pearson Education.

[17] Harmer, J. (2007). The practice of English language teaching (Fourth edition). Harlow: Pearson Education.

[18] Hatch, E. \& Farhady, H. (1982). Research design and statistics. For applied linguistics. Rowley, Mass: Newbury House.

[19] Haynes, N.M. (1998). Creating safe and caring communities. Development program schools. Journal of Negro Education, Vol 65, 308-314.

[20] Knowles, M.S. (1976). The modern practice of adult education. New York: Association Press.

[21] Littlejohn, A. (2008). The tip of the iceberg: Factors affecting learner motivation. RELC Journal, Vol. 39 (2), 214 -225.

[22] Littlewood, W. T. (1998). Foreign and second language learning: language-acquisition research and its implications for the classroom. New York: Cambridge University Press.

[23] Lumsden, L.S. (1994). Student motivation to learn. ERIC Digest, No. 92. Retrieved on April 142011 from www.naeareston.org.

[24] Noels, K.A., et al. (2001). Intrinsic, extrinsic, and integrative orientations of French Canadian learners of English. The Canadian Language Review, Vol. 57, 424-442.

[25] Nunan, D. (1992). Collaborative language learning and teaching. Cambridge: Cambridge University Press.

[26] Paige, R. (2001). Tools for student success. Retrieved on May 42011 from www.ed.gov.

[27] Pearse, P.D.E. (2000). Success in English teacher. Oxford. Oxford University Press.

[28] Poplin, M. \& Weeres, J. (1993). Listening to the learners' level. The executive educators, Vol. 15, 14-19.

[29] Rubin, J. (1975). What the "good language learner" can teach us? TESOL quarterly, Vol. 9 (1), 41-51.

[30] Seliger, H. \& Shohamy, E. (1989). Second Language Research Methods. New York: Oxford University Press.

[31] Sparks, D. (2000). Issues at the table: Teacher quality and student achievement become bargaining matters: An interview with Julia Koppich. Journal of Staff Development, 21(2), 53-58.

[32] Tudor, I. (1996). Learner-Centeredness as language education. Cambridge: Cambridge University Press.

[33] Underwood, M. (1987). Effective class management. New York: Longman.

[34] Vallerand, R. (1997). Toward a hierarchal modal of intrinsic motivation. In M.P. Zanna (Ed). Advances in Experimental Social Psychology, Vol. 29, 271-360.

[35] Wiersma, W. (1995). Research methods in education. Mass: Needham Heights.

[36] Willing, K. (1988). Learning styles in adults migrants education. Sydney: National centre for English language teaching research.

[37] Wood, W.L. (1998). Foreign and second language learning. Cambridge. Cambridge University Press.

[38] Yule, G.T.E. (1989). Focus on the language learners - Approaches to identifying and meeting the needs of second language learners. Oxford: Oxford University Press. 
Luu Trong Tuan is currently an EFL teacher at Ho Chi Minh City University for Natural Resources and Environment. He received his M.TESOL from Victoria University, Australia in 2004. Besides his focus on TESOL, his recent publications such as Language Transfer is Cultural Transfer between Communities, Social Sciences Review, No. 11, 2004, pp. 60-63; and Principles for Scientific Translation, Social Sciences Review, No. 8, 2004, pp. 63-67; and Building Vietnamese Medical Terminology via Language Contact, Australian Journal of Linguistics, Vol. 29, No. 3, September 2009, pp. 315-336 show his interest in language contact and translation areas. 